\title{
Risk assessment of exposure to volatile organic compounds in the holy city of Makkah
}

\author{
T. Habeebullah \\ The Two Holy Mosques Institute for Hajj and Umrah Research, \\ Umm Al Qura University, Makkah, Saudi Arabia
}

\begin{abstract}
Millions of pilgrims arrive in Makkah every year to perform Hajj and/or Umrah. The increase of pilgrim numbers is accompanied by the increase of their daily activities as well as the increase in the demands of transportation means. Consequently, considerable quantities of either gaseous or solid pollutants are emitted to the atmosphere. The present study focuses on volatile organic compounds (VOCs) where there is a lack of studying VOCs as air toxins and it is considered as the first of its kind in Saudi Arabia. The goals of the current work aimed to: I) develop adequate air monitoring technology (methodology) for VOCs; II) assess the life time of cancer and non-cancer risk; and III) enhance research capacity on VOCs air pollution and health risk analysis.

The ambient VOCs samples (during Hajj season 1431H) were collected from different sites (Al-Shbaikah, Al-Aziziah and Mina). Fourteen (14) VOCs compounds (benzene, toluene, ethylbenzene, p-xylene, m-xylene, o-xylene, 1,2,4-trimethylbenzene, vinyl chloride, styrene, chlorotolune, 1,2dichlorobenzene, 1,3-dichlorobenzene, 1,2,4-trichlorobenzene and 1,2,3trichlorobenzene) were targeted in this study. The mean concentrations of most abundant group of VOCs; Benzene, Toluene, Ethylbenzene, and $\Sigma$ Xylene in El Shebaka were $8.11 ; 15.85 ; 9.20 ; 8.45 \mu \mathrm{g} / \mathrm{m}^{3}$, respectively during day time and $31.44 ; 37.80 ; 42.03$ and $38.71 \mu \mathrm{g} / \mathrm{m}^{3}$ during night time, respectively. In AlAziziah, the values measured were $11.75 ; 9.42 ; 48.8$; and $33.49 \mu \mathrm{g} / \mathrm{m}^{3}$ during day time, meanwhile, during night time were $4.78 ; 6.67 ; 8.45$; and $18.56 \mu \mathrm{g} / \mathrm{m}^{3}$, respectively. The concentrations of benzene, toluene, ethylbenzene, xylenes in the air were significantly higher than other species.

The lifetime cancer and noncancer risks for the population groups exposed to VOCs were also assessed in detail. Noncancer risk was estimated in relation to
\end{abstract}


the reference hazard level of 1.0. It was found that benzene may be the most important cause of both cancer and noncancer risk.

Keywords: ambient volatile organic compounds (VOCs), Makkah, Hajj, air quality.

\section{Introduction}

Urban air pollution is rapidly becoming an environmental problem of public concern during the last few decades [1]. Volatile organic compounds (VOCs) are organic chemicals and a major group of pollutants, and receive increasing concern worldwide [2]. However, all organic compounds contain carbon, and organic chemicals are the basic chemicals found in all living things and in all products derived from living things. VOCs include gasoline, industrial chemicals such as benzene, solvents such as toluene and xylene, and perchloroethylene (principal dry cleaning solvent) [2]. Sources of VOCs emission are both anthropogenic and natural. The major anthropogenic sources in the urban environment are vehicle exhaust, gasoline evaporation, emissions from the use of solvents, and gas leakage from natural gas and liquefied petroleum gas (LPG) [3].

VOCs are hazardous air pollutants, which cause various acute health problem as well as carcinogenic risk. Under this situation, the current study considers VOCs as an important issue in ambient environmental matters. National Environmental authorities have instructed plans to implement countermeasure for VOCs [3-9]. In addition, the presence of VOCs in the atmosphere plays an important role in the formation of ground level ozone, photochemical oxidants and smog episodes [10]. Exposure to the ambient air pollution poses a high risk to urban population. The sensitive groups (children and elderly) are certainly more vulnerable from the resulting health effects $[8,11,12]$. Besides, many street vendors who are working on the streets exposes them to continuous air pollution from traffic including toxic pollutants such as PAHs, VOCs and fine particulate matters $\left(\mathrm{PM}_{2.5}\right)$ [12]. These people thus have much higher exposure to ambient air pollution both in terms of concentration and time period [1].

Many studies, [1, 7, 8, 13-24], were conducted and examined the occupational exposure to VOCs from gasoline vapor emissions. Accordingly, it is common that the workers are exposed to highly elevated VOCs levels compared with ambient levels by inhalation, ingestion, and dermal contact. Most of the toxicants assessed are VOCs that remain as gases when emitted into the air. These compounds are not subject to appreciable deposition to soil, surface waters, or plants. Therefore, human exposure does not occur to any appreciable extent via ingestion or dermal exposure.

The current study is conducted in three locations in the city of Makkah (AlShbaikah, Al-Aziziah, and Mina) during Hajj season 1431H. This study is considered the first of its kind to be performed in Saudi Arabia to evaluate concentration and risk assessment. Herein only four VOC compounds (Benzene, Toluene, Ethylbenzene and Xylene (BTEX)) are being considered. 


\section{Materials and methods}

\subsection{Site description}

The Holy City of Makkah is located at $80 \mathrm{~km}$ from the Red Sea (Latitude $19^{\circ} 25^{\prime}$ $21^{\prime \prime}$ North Meridian 46 49' 39"); the average elevation is approximately $277 \mathrm{~m}$ above sea level. The city is situated between mountain ranges, which control the contemporary expansion of the urban areas; however and due to its importance the city has dense population and nearly accommodates 1,700,000 [25]. The city centre is around the Holy Mosque (Haram), which altitude is lower than most of the city. Three sampling locations were selected in the present study as shown in Fig. 1. The ambient air samples were collected from the selected sites (AlShbaikah near to Haram; Al-Aziziah; and Mina) to represent different activities during Hajj season of $1431 \mathrm{H}$.

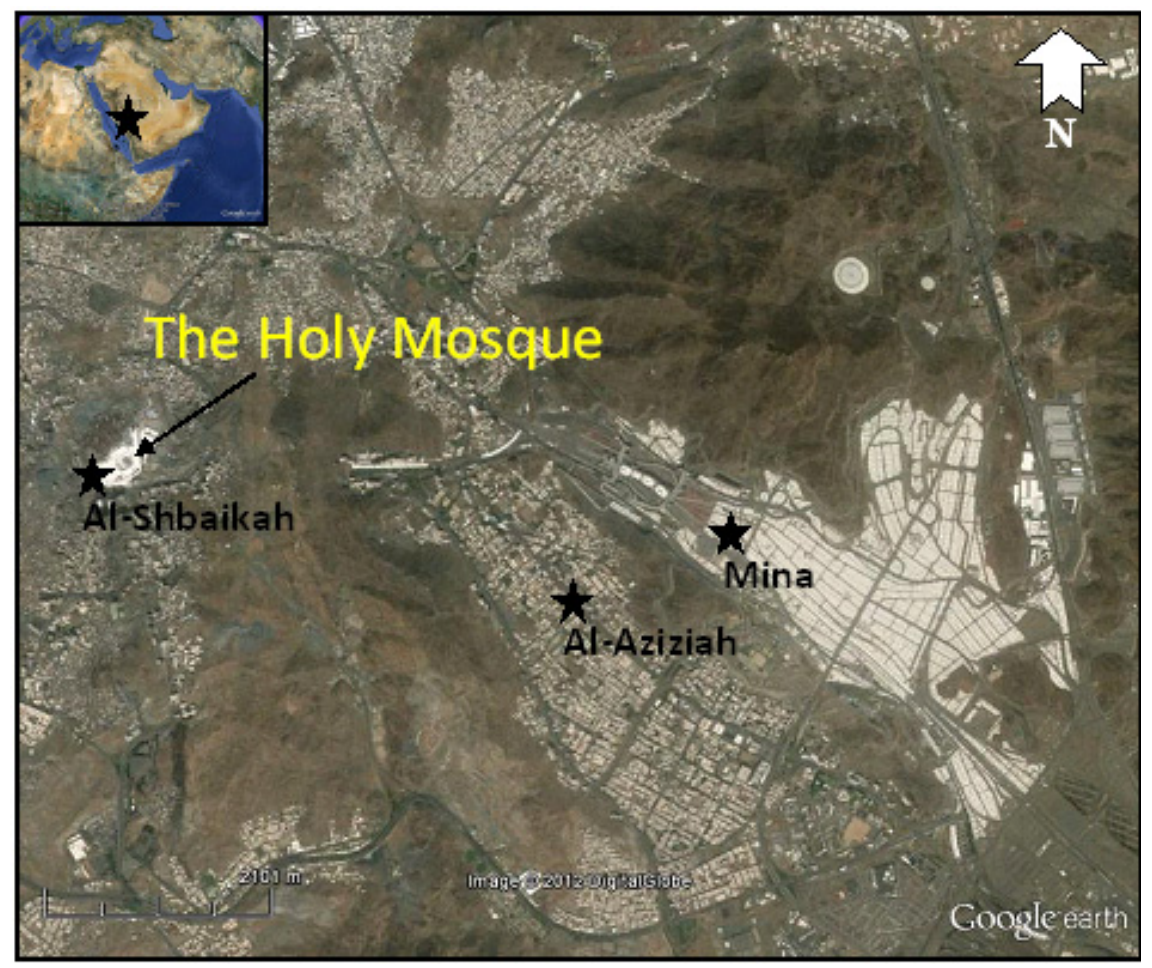

Figure 1: $\quad$ Map of Makkah showing the sampling locations.

\subsection{Sampling and analysis}

Ambient VOCs samples were collected according to a standard method developed by using activated charcoal tubes (ORBOTM-32 activated coconut 
charcoal (20/40)) for the collection [26, 27]. The collection tubes (Supelco, Inc., Bellefonte, PA) contained $150 \mathrm{mg}$ of coconut charcoal were sub-divided into two portions of 100 and $50 \mathrm{mg}$ : the front portion of $100 \mathrm{mg}$ was used to collect the VOCs, while the $50 \mathrm{mg}$ backup section was intended to determine if solvent breakthrough occurred from the front section. Air was drawn through the charcoal tubes, using a pump calibrated to draw $0.20 \mathrm{~L} / \mathrm{min}$. After sampling, the tubes were closed and wrapped in foils and identified by labels. Maximum duration time in refrigerator was 5 days, separated from other samples. During the sampling procedure, one charcoal tube was opened at the sample site and then the ends capped, which served as a blank. The samples and blanks tubes were put into special plastic bags that were tightly closed and kept at $-10^{\circ} \mathrm{C}$ in a freezer until analysis, not more than 15 days. BTEX compounds were extracted from activated charcoal using $1 \mathrm{ml}$ carbon disulphide $\left(\mathrm{CS}_{2}\right)$. Operational parameters were optimized and quantitative recovery was obtained using $\mathrm{CS}_{2}$ as the extraction solvent $[26,27]$. Determination of BTEX compounds was carried out by gas chromatography using a flame ionization detector (GC/FID).

\subsection{Health risk assessment}

The health risk assessment focused on chronic exposure to compounds that may cause cancer or other toxic effects, rather than on acute toxicity. The main exposure route of interest was inhalation [6]. The inhalation intake was calculated by averaging daily intake over the exposure period. The carcinogenic and non-carcinogenic intakes of VOCs for gas service station workers were calculated as shown in eqn. (1):

$$
\mathrm{I}=(\mathrm{C} \times \mathrm{ET} \times \mathrm{EF} \times \mathrm{ED}) / \mathrm{AT}
$$

where I is the inhalation intake $\left(\mu \mathrm{g} / \mathrm{m}^{3}\right), \mathrm{C}$ is the concentration of the compound in the personal air sample $\left(\mu \mathrm{g} / \mathrm{m}^{3}\right)$, ET is the exposure time ( $\mathrm{hr} /$ day), EF is the exposure frequency (days/year), ED is the exposure duration (years), and AT is an average lifetime (years). Inhalation exposure is always related to exposure frequency, duration, and quantity (dose) and activity pattern. The inhaled compounds were assumed to be totally absorbed for risk calculations in some studies [6, 28]. In this assessment, risk estimates for VOCs with a cancer endpoint were expressed in terms of the probability of developing cancer from a lifetime of continuous exposure to VOCs. The lifetime cancer risk was estimated using eqn. (2):

$$
\text { Cancer risk }=\mathrm{I}\left(\mu \mathrm{g} / \mathrm{m}^{3}\right) \times \text { cancer unit risk factors }\left(\mu \mathrm{g} / \mathrm{m}^{3}\right)^{-1}
$$

The non-cancer risk is expressed in terms of the hazard quotient (HQ) as shown in eqn. (3), which is the estimated ground level concentration divided by the reference exposure level (REL) for a single substance and a particular endpoint. The REL is an exposure level at, or below which, no non-cancer adverse health effect is anticipated to occur in a human population exposed for a specific duration [13]. The non-cancer health impacts were expressed as the hazard index (HI) as shown in eqn. (4), which is determined by calculating the HQ for a compounds and summing all of the HQ at investigated location [29]. 


$$
\begin{gathered}
\mathrm{HQ}=\mathrm{I}\left(\mu \mathrm{g} / \mathrm{m}^{3}\right) / \mathrm{RELs}\left(\mu \mathrm{g} / \mathrm{m}^{3}\right) \\
\mathrm{HI}=\mathrm{HQ}_{1}+\mathrm{HQ}_{2}+\mathrm{HQ}_{3}+\ldots . . \mathrm{HQ}_{\mathrm{n}}
\end{gathered}
$$

Table 1 summarizes the exposure and risk assessment factors Risk characterization required combining the estimated exposure concentrations with toxicity data and toxicity values for BTEX compounds to provide a quantitative estimate of the potential health impacts. The potential for adverse effects was increased as exposures further exceed the reference dose.

\begin{tabular}{|c|c|c|c|}
\hline \multicolumn{2}{|l|}{ Exposure settings } & Value & Source \\
\hline \multicolumn{2}{|l|}{ Exposure time (ET) } & 24 h /day & \multirow{4}{*}{ Surveys } \\
\hline \multicolumn{2}{|l|}{ Exposure frequency (EF) } & 15 day /year & \\
\hline \multicolumn{2}{|c|}{ Exposure duration : carcinogenic (ED) } & 2 year & \\
\hline \multicolumn{2}{|c|}{ Exposure duration : non-carcinogenic (ED) } & 2 year & \\
\hline \multicolumn{2}{|c|}{ Average life time : carcinogenic (AT) } & 70 year & \multirow{7}{*}{ [13] } \\
\hline \multicolumn{2}{|c|}{ Average life time : non-carcinogenic (AT) } & 70 year & \\
\hline \multicolumn{2}{|c|}{ Cancer Unit Risk Factors for BTEX } & $2.9 \mathrm{E}-05\left(\mu \mathrm{g} / \mathrm{m}^{3}\right)-1$ & \\
\hline \multirow{4}{*}{$\begin{array}{l}\text { Chronic Inhalation Reference } \\
\text { Expose Levels (RELs) }\end{array}$} & benzene & $6.0 \mathrm{E}+01 \mu \mathrm{g} / \mathrm{m}^{3}$ & \\
\hline & toluene & $3.0 \mathrm{E}+02 \mu \mathrm{g} / \mathrm{m}^{3}$ & \\
\hline & $\begin{array}{l}\text { ethyl } \\
\text { benzene }\end{array}$ & $2.0 \mathrm{E}+03 \mu \mathrm{g} / \mathrm{m}^{3}$ & \\
\hline & xylene & $7.0 \mathrm{E}+02 \mu \mathrm{g} / \mathrm{m}^{3}$ & \\
\hline
\end{tabular}

Table 1: The exposure and risk assessment factors.

Inhalation rates were taken into account when studying dose-response relationships and in developing the screening values. Exposure doses from inhalation of BTEX in air were calculated as shown in eqn. (5):

$$
\mathrm{D}=(\mathrm{C} X \mathrm{IR} X \mathrm{EF}) / \mathrm{BW}
$$

where, $D$ is exposure dose $(\mathrm{mg} / \mathrm{kg} /$ day $), C$ is contaminant concentration $\left(\mathrm{mg} / \mathrm{m}^{3}\right)$, IR is intake rate $\left(\mathrm{m}^{3} / \mathrm{day}\right), \mathrm{EF}$ is exposure factor (unit less) and BW is body weight $(\mathrm{kg})$. Default air intake rates were: $4.5 \mathrm{~m}^{3} /$ day for infant (less than 1 year), $10 \mathrm{~m}^{3} /$ day for child (6-8 years), $12 \mathrm{~m}^{3} /$ day for girl (12-14years), $15 \mathrm{~m}^{3} /$ day for boy (12-14 years), $11.3 \mathrm{~m}^{3} /$ day for female (19-65+ years) and $15.2 \mathrm{~m}^{3} /$ day for male $(19-65+$ years $)[30]$.

\section{Results and discussion}

There was a lack on the information and data in Saudi Arabia regarding to VOCs concentration and level in ambient air, therefore, the present study was designed to fill the gap and suggested further research studies for such new hazardous air pollutants in the holy city. Consequently, the current study was surveyed some 
published data and literature to draw a picture about the levels of VOCs in ambient air in different parts of the world.

Fourteen (14) VOCs compounds (benzene, toluene, ethylbenzene, p-xylene, m-xylene, o-xylene, 1,2,4-trimethylbenzene, vinyl chloride, styrene, chlorotolune, 1,2-dichlorobenzene, 1,3-dichlorobenzene, 1,2,4-trichlorobenzene and 1,2,3-trichlorobenzene) were targeted in this study. But risk assessment calculation was concerned on only BTEX compounds. Statistical analysis of the most abundant group of VOCs (BTEX); Benzene, Toluene, Ethylbenzene, and Xylene in the three studied locations are shown in the table 2.

Table 2: $\quad$ The mean VOCs concentrations $\left(\mu \mathrm{g} / \mathrm{m}^{3}\right)$ at investigated sites.

\begin{tabular}{|c|c|c|c|c|c|c|c|}
\hline \multicolumn{2}{|c|}{ site } & Al-Shbaikah & Al-Aziziah & Mina & Mean & Min. & Max. \\
\hline \multirow{3}{*}{ Benzene } & am & 8.1 & 11.8 & 3.2 & 7.7 & 3.2 & 11.8 \\
\cline { 2 - 8 } & $\mathrm{pm}$ & 31.4 & 4.8 & 34 & 23.4 & 4.8 & 34 \\
\hline \multirow{3}{*}{ Toluene } & $\mathrm{am}$ & 15.9 & 9.4 & 8.1 & 11.1 & 8.1 & 15.9 \\
\cline { 2 - 8 } & $\mathrm{pm}$ & 37.8 & 6.7 & 52.4 & 32.3 & 6.7 & 52.4 \\
\hline \multirow{2}{*}{$\begin{array}{c}\text { Ethyl } \\
\text { benzene }\end{array}$} & $\mathrm{am}$ & 9.2 & 18.8 & 6.2 & 11.4 & 6.2 & 18.8 \\
\cline { 2 - 8 } & $\mathrm{pm}$ & 42 & 8.5 & 35.5 & 28.7 & 8.5 & 42 \\
\hline \multirow{2}{*}{\begin{tabular}{c} 
Xylene \\
\cline { 2 - 8 }
\end{tabular}} & $\mathrm{am}$ & 2.8 & 11.2 & 1.9 & 5.3 & 1.9 & 11.2 \\
\cline { 2 - 8 } & $\mathrm{pm}$ & 12.9 & 6.2 & 21.5 & 13.5 & 6.2 & 21.5 \\
\hline \multirow{2}{*}{$\begin{array}{c}\text { Total } \\
\text { VOCs }\end{array}$} & $\mathrm{am}$ & 47.3 & 91.7 & 26.9 & 55.3 & 26.9 & 91.7 \\
\cline { 2 - 8 } & $\mathrm{pm}$ & 197.4 & 51.6 & 219.9 & 156.3 & 51.6 & 219.9 \\
\hline
\end{tabular}

Max.; maximum value; Min.: minimum value; am: day-time; pm: night-time

Table 2 shows that BTEX concentrations were higher at Mina than those found in Al-Shbaikah and Al-Aziziah during night-time and lower during daytime. The observed levels of BTEX in Al-Shbaikah was due to the high traffic density, since this site was very close to the holy mosque surrounded by many street intersections and roads leading to Haram in addition to the most commercial and heaviest traffic areas in Makkah. The maximum concentrations of total VOCs were found at Mina site $\left(219.9 \mu \mathrm{g} / \mathrm{m}^{3}\right)$ during night-time. The higher levels of VOCs in Mina area was due to the highest activity of Hajj in the valley where pilgrims move to Mina during day-time and reached to the highest density at night-time. Compared to Al-Shbaikah and Al-Aziziah, total VOCs concentrations in Mina during day-time of Hajj days were the lowest at Mina area. In contrast, the concentrations of total VOCs were highest than other two sites during night-time of Hajj days. These concentrations were mostly caused by traffic. Therefore, the increase in traffic density will increase both exhaust and vehicle evaporative emission $[14,31]$.

In this study, most VOCs Concentrations were higher than other concentration reported in different countries. In China (Beijing city), the mean 
mass concentration of total VOCs was $132.6 \mu \mathrm{g} / \mathrm{m}^{3}$. This value was mostly lower than most of the current results [21]. In general, comparison between the organic compounds obtained in this study was extremely higher than later research.

Table 3 expresses the VOCs risk assessment calculations at investigated sites. In this table, it can be noticed that the mean inhalation intake of VOCs were 159.9, 232.2, 205.1 and $96.7 \mu \mathrm{g} / \mathrm{m}^{3}$ for Benzene, Toluene, Ethyl benzene and Xylene, respectively. The inhalation intakes of VOCs varied from place to place. The minimum inhalation intake of VOCs was found at Mina site $\left(19.0 \mu \mathrm{g} / \mathrm{m}^{3}\right)$ during day-time. While, the maximum inhalation intake of VOCs was found at Al-Shbaikah site $\left(432.3 \mu \mathrm{g} / \mathrm{m}^{3}\right)$ during night-time.

Table 3: $\quad$ The VOCs risk assessment calculations at investigated sites.

\begin{tabular}{|c|c|c|c|c|c|c|c|c|}
\hline \multirow[b]{2}{*}{ parameter } & \multirow{2}{*}{$\frac{\text { site }}{\text { VOCs }}$} & \multicolumn{2}{|c|}{ Al-Shbaikah } & \multicolumn{2}{|c|}{ Al-Aziziah } & \multicolumn{2}{|c|}{ Mina } & \multirow[b]{2}{*}{ Mean } \\
\hline & & am & $\mathrm{pm}$ & am & $\mathrm{pm}$ & am & $\mathrm{pm}$ & \\
\hline \multirow{4}{*}{$\begin{array}{l}\text { inhalation } \\
\text { intake } \\
\left(\mathrm{ug} / \mathrm{m}^{3}\right)\end{array}$} & benzene & 83.4 & 323.4 & 120.9 & 49.2 & 32.5 & 350.0 & 159.9 \\
\hline & toluene & 163.0 & 388.8 & 96.9 & 68.6 & 83.0 & 538.9 & 223.2 \\
\hline & Ethyl benzene & 94.6 & 432.3 & 193.4 & 86.9 & 63.8 & 365.3 & 206.1 \\
\hline & Xylene & 29.0 & 132.7 & 114.8 & 63.7 & 19.0 & 221.1 & 96.7 \\
\hline \multirow[b]{5}{*}{ cancer risk } & benzene & 0.002 & 0.009 & 0.004 & 0.001 & 0.001 & 0.010 & 0.005 \\
\hline & toluene & 0.005 & 0.011 & 0.003 & 0.002 & 0.002 & 0.016 & 0.006 \\
\hline & Ethyl benzene & 0.003 & 0.013 & 0.006 & 0.003 & 0.002 & 0.011 & 0.006 \\
\hline & Xylene & 0.001 & 0.004 & 0.003 & 0.002 & 0.001 & 0.006 & 0.003 \\
\hline & Total & 0.011 & 0.037 & 0.015 & 0.008 & 0.006 & 0.043 & 0.020 \\
\hline \multirow{5}{*}{$\begin{array}{c}\text { Hazard } \\
\text { Quotient }\end{array}$} & benzene & 1.39 & 5.39 & 2.01 & 0.82 & 0.54 & 5.83 & 2.66 \\
\hline & toluene & 0.54 & 1.30 & 0.32 & 0.23 & 0.28 & 1.80 & 0.74 \\
\hline & Ethyl benzene & 0.05 & 0.22 & 0.10 & 0.04 & 0.03 & 0.18 & 0.10 \\
\hline & Xylene & 0.04 & 0.19 & 0.16 & 0.09 & 0.03 & 0.32 & 0.14 \\
\hline & $\mathrm{HI}$ & 2.02 & 7.09 & 2.60 & 1.18 & 0.88 & 8.13 & 3.65 \\
\hline
\end{tabular}

Also, Table 3 shows that cancer risk of BTEX ranged between 0.001-0.013 (at Al-Shbaikah), 0.001-0.005(at Al-Aziziah) and 0.001-0.016 (at Mina). Hazard Quotient (HQ) for noncancer risk was found to be 2.66 for Benzene, 0.74 for Toluene, 0.10 for Ethyl benzene and 0.14 for Xyelene. The ratio of the potential exposure to the BTEX was anticipated to show that there were no adverse effects. Moreover, if the calculated HQ was equal or less than $1(\mathrm{HQ} \leq 1)$, then no adverse health effects were expected as a result of exposure. However, if the HQ was greater than $1(\mathrm{HQ}>1)$, then adverse health effects were possible. Therefore, the HQ cannot be translated to a probability that adverse health effects would occur and it was unlikely to be proportional to risk. It was especially important to note that an HQ exceeding 1 does not necessarily mean that adverse effects will occur. 
The risk of health effects from inhaling BTEX were classified into: short-term (acute) exposures as hours to days or long-term (chronic) exposures as years to even lifetime. Breathing low levels of VOCs for long periods of time may increase some people's risk of health problems. Several studies, $[4,5,8,14,21$, $26,32-40$ ] suggest that exposure to VOCs may make symptoms worse in people who have asthma or are particularly sensitive to chemicals. These were much different exposures than occupational exposures to VOCs. Common symptoms of exposure to VOCs included: i) Short-Term (Acute) to high levels of VOCs

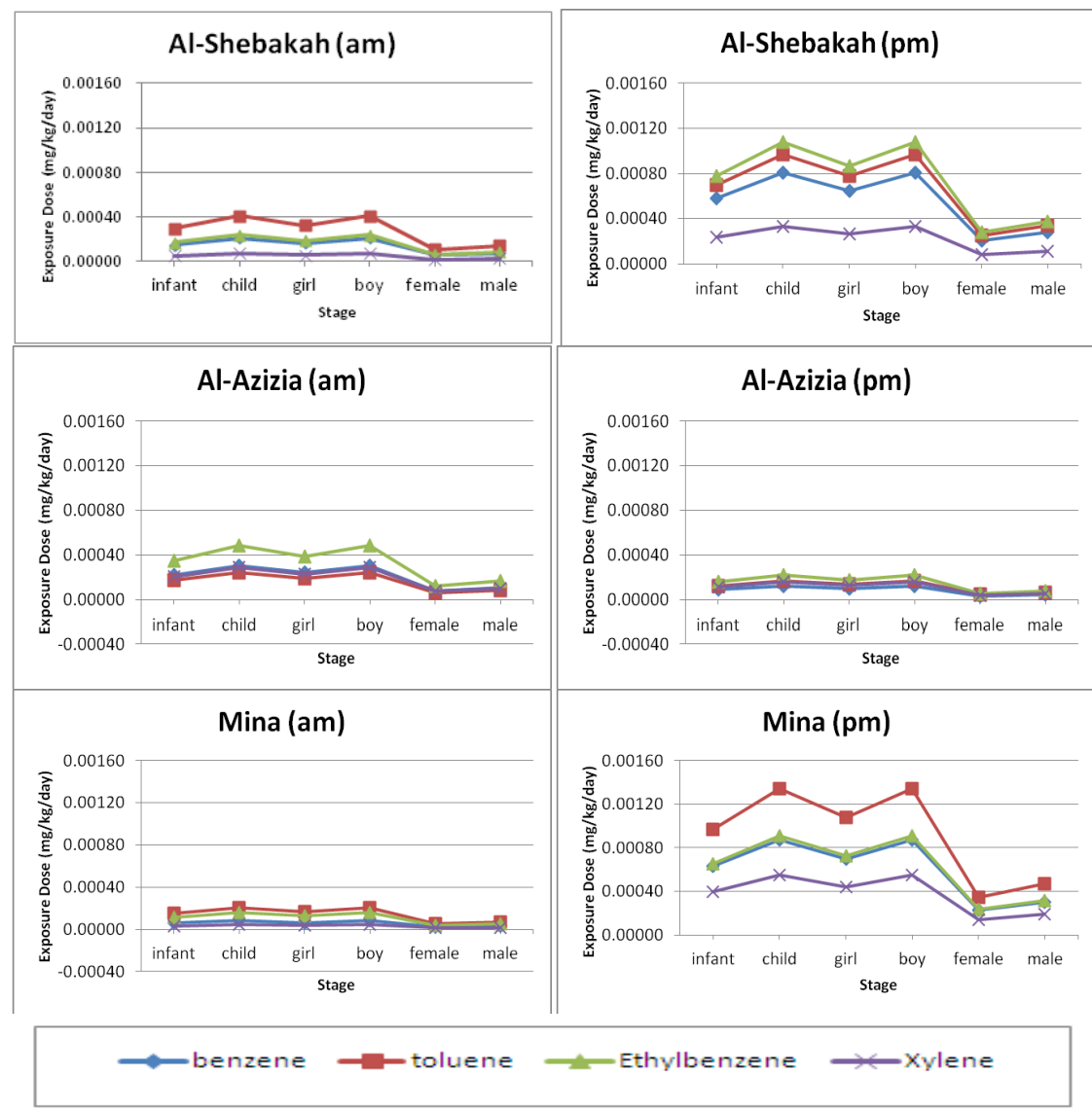

Figure 2: $\quad$ Exposure dose (mg/kg/day) at investigated sites (Al-Shbaikah, AlAziziah and Mina) for different stages (infant, child, girl, boy, female and male). 
(Eye, nose and throat irritation, Headaches, Nausea/Vomiting, Dizziness, immune effects in infants or children and Worsening of asthma symptoms. ii) Long-Term (Chronic) to high levels of VOCs Increased risk of Cancer, Liver damage, Kidney damage and Central Nervous System damage [8, 11, 12].

Fig. 2 shows that the exposure dose at investigated sites. It was found that exposure dose ranged between 0.00003 to $0.00097 \mathrm{mg} / \mathrm{kg} /$ day for infant (less than 1 year), from 0.00005 to $0.00135 \mathrm{mg} / \mathrm{kg} / \mathrm{day}$ for child (6-8 years), from 0.00004 to $0.00108 \mathrm{mg} / \mathrm{kg} /$ day for girl (12-14 years), from 0.00005 to 0.00135 $\mathrm{mg} / \mathrm{kg} /$ day for boy (12-14 years), from 0.00001 to $0.00035 \mathrm{mg} / \mathrm{kg} / \mathrm{day}$ for female (19-65+ years) and from 0.00002 to $0.00047 \mathrm{mg} / \mathrm{kg} /$ day for male (19-65+ years). Moreover, this figure was highlighted that the maximum exposure dose for female $(0.00001 \mathrm{mg} / \mathrm{kg} / \mathrm{day})$, was recorded in Mina site during day-time. While, the minimum exposure dose for child $(0.00135 \mathrm{mg} / \mathrm{kg} /$ day $)$, was recorded in the same site (Mina) during night-time.

\section{Conclusions}

The current study indicated that exposure to aromatic VOCs is mainly influenced by different activities in the holy city. Moreover, risk assessment and exposure dose for BTEX in the city of Makkah was found to be within guidelines levels. Therefore, it is highly important to study risk assessment (inhalation intake, cancer risk and noncancer risk) for VOCs levels in indoor where people spend most of their time at home, offices, malls and closed buildings. International studies and Environmental Protection Agency (EPA) found concentrations of VOCs in indoor air commonly to be 2 to 5 times greater than an outdoor air and sometimes far greater. Also, it is recommended to study VOCs over one complete year indoor and outdoor to investigate the seasonal variations.

\section{References}

[1] Cheng, L., Fu, L., Angle, P. and Sandhu, H.S., Seasonal Variations of Volatile Organic Compounds in Edmonton Alberta. Atmospheric Environment, 31(2), pp. 239-246, 1997.

[2] National Institute for Occupational Safety and Health (NIOSH), Method 2549 in the NIOSH Manual of Analytical Methods, fourth ed. US Department of Health and Human Services, Center for Disease Control, NIOSH, Cincinnati, OH. May 15, 1996.

[3] National Institute for Occupational Safety and Health (NIOSH), Chemical listing and documentation of revised IDLH values, 2003.www.cdc.gov/niosh/intridl4.html

[4] Nelson, P.F. and Quigley, S.M., The hydrocarbon composition of exhaust emitted from gasoline fueled vehicles. Atmospheric Environment, 18(1), pp. 79-87, 1984.

[5] Occupational Safety and Health Administration (OSHA), Computerized information system. Washington, DC: U.S. Department of Labor, 1994. 
[6] Rumchev, K., Spickett, J., Bulsara, M., Phillips, M. and Stick, S., Association of domestic exposure to volatile organic compounds with asthma in young children. Thorax, 59(9), pp. 746-751, 2004.

[7] Na, K., Kim, Y.P., Moon, I. and Moon, K.C., Chemical composition of VOC major emission sources in the Seoul atmosphere. Chemosphere, 55(4), pp. 585-594, 2004.

[8] Environmental, Health, Safety, Transport and Storage guidelines (EHSTSG). Styrene Monomer, Belgium, 2007.

[9] Liu, Y., Shao, M., Lu, S., Chang, C., Wang, J. and Fu, L., Source apportionment of ambient volatile organic compounds in the Pearl River Delta, China: Part II. Atmospheric Environment, 42(25), pp. 6261-6274, 2008.

[10] Air Quality Guidelines for Europe (AQGE), World Health Organization Regional Office for Europe (WHO), Regional Publications, European Series, No. 91, Second Edition, 2000.

[11] Adgate, J.L., Church, T.R., Ryan, A.D,. Ramachandran, G., Fredrickson, A.L., Stock, T.H., Morandi, M.T. and Sexton, K., Outdoor, indoor, and personal exposure to VOCs in children. Environ Health Perspect., 112(14), pp. 1386-1392, 2004.

[12] Environmental Protection Agency (EPA). Exposure factors handbook, 1997. www.epa.gov/ncea/pdfs/efh/front.pdf.

[13] American Conference of Governmental Industrial Hygienists (ACGIH). Threshold limit values for chemical substances and physical agents and biological exposure indices. Cincinnati, OH, 1994.

[14] Nasralla, M. and Albar, O., Particulate in Makkah Atmosphere, The Custodian of the Two Holy Mosques Institute for Hajj Research, Annual Report, Makkah, Saudi Arabia, 2005.

[15] Hartle RW, Young RJ. Occupational benzene exposure at retail automotive service stations. Draft report. Division of Surveillance. National Institute for Occupational Safety and Health. Cincinnati, Ohio, USA. 1997.

[16] Muller, E., Diab, R.D., Binedell, M. and Hounsome, R., Health risk assessment of kerosene usage in an informal settlement in Durban, South Africa. Atmospheric Environment, 37, pp. 2015-22, 2003.

[17] American Conference of Governmental Industrial Hygienists (ACGIH). Documentation of the threshold limits values and biological exposure indices. 6th edition. Cincinnati, OH, 1991.

[18] American Conference of Governmental Industrial Hygienists (ACGIH). Guide to Occupational Exposure Values. Cincinnati, OH, 2003.

[19] Hoddinott, K.B. and Lee, A.P., The use of environmental risk assessment methodologies for an indoor air quality investigation. Chemosphere, 41(12), pp. 77-84, 2000.

[20] Hsieh, C.C. and Tsai, J., VOC Concentration Characteristics in Southern Taiwan. Chemosphere, 50(4), pp. 545-556, 2003.

[21] Interim Guidance on the Water Quality (IGWQ) Regulations 2000 (England) and the Water Supply (Water Quality) Regulations 2001 (Wales). Drinking Water Inspectorate, 2003. 
[22] International Agency for Research on Cancer (IARC). Monographs on the Evaluation of Carcinogenic Risk to Humans, Supplement 7. Lyons. USA. 1987.

[23] Isidorov, V.A., Zenkevich, I.G. and Ioffe, B.V., Volatile organic compounds in solfataric gases. Journal of Atmospheric Chemistry, 10(3), pp. 329-340, 1990.

[24] Mendell, M. J., Indoor residential chemical emissions as risk factors for respiratory and allergic effects in children: A review. Indoor Air, 17(4), pp. 259-277, 2007.

[25] Jo, W. and Song, K., Exposure to volatile organic compounds for individuals with occupations associated with potential exposure to motor vehicle exhaust and/or gasoline vapor emissions. Science of the Total Environment, 269(1-3), pp. 25-37, 2001.

[26] Edgerton, S.A., Holdren, M.W., Smith, D.L. and Shah, J.J., Inter-urban comparison of ambient volatile organic compound concentrations in US cities. Journal of Air Pollution and Control Association, 39(5), pp. 729732. 1989.

[27] Chemical Book (CB), 2010. www.chemicalbook.com/Chemical Product Property EN_CB9245073.htm

[28] Canadian Environmental Protection Act (CEPA). Priority Substance List, Assessment Report, Xylenes. Government of Canada, Environment Canada, Health Canada. Canada Communication Group Publishing, 1993.

[29] California Environmental Protection Agency (Cal/EPA). The Air Toxics Hot Spots Program Guidance Manual for Preparation of Health Risk Assessments. California, USA, 2003.

[30] National Institute for Occupational Safety and Health (NIOSH), Recommendations for occupational safety and health: Compendium of policy documents and statements. Cincinnati, OH: U.S. Department of Health and Human Services, Public Health Service, Centres for Disease Control, National Institute for Occupational Safety and Health, DHHS (NIOSH) Publication, No. 92-100, 1992.

[31] Sweet, C. W. and Vermette, S. J., Toxic volatile organic compounds in urban air in Illinois. Environmental Science Technology. 26(1), pp. 165173, 1992.

[32] Monod, A., Sive, B.C., Avino, P., Chen, T., Blake, D.B. and Rowland, F.S., Monoaromatic Compounds in Ambient Air of Various Cities: A Focus on Correlations between the Xylenes and Ethylbenzene. Atmospheric Environment, 35(1), pp. 135-149, 2001.

[33] United States Environmental Protection Agency (USEPA). Cancer Risk from Outdoor Exposure to Air Toxics. PA- 450_1- 90-004a. Research Triangle Park, NC, USA. 1990.

[34] Jones, A. P., Indoor air quality and health. Atmospheric Environment, 33(28), pp. 4535-4564, 1999.

[35] United States Environmental Protection Agency (USEPA). Integrated Risk Information System, 1998. www.epa.gov/iris. 
[36] California Environmental Protection Agency (Cal/EPA). Technical Support Document for Describing Available Cancer Potency Factors. California, USA, 2005.

[37] Central Department of Statistics and Information (CDSI). Saudi Arabia, 2010. www.cdsi.gov.sa/englishChemical Book (CB), 2010.

[38] Kearney, C.A. and Dunham, D.B., Gasoline vapor exposures at a high volume service station. American Industrial Hygiene Association, 47(9), pp. 535-39, 1986.

[39] Khoder M.I., Ambient levels of volatile organic compounds in the atmosphere of Greater Cairo, Atmospheric Environment, 41(3), pp. 554566, 2007.

[40] World Health Organization (WHO), Indoor air quality: organic pollutants, Report on a WHO Meeting, Berlin, EURO Reports and Studies 111, Copenhagen, 1989. 